\title{
Assessing Organic Matter and Organic Carbon Contents in Soils of Created Mitigation Wetlands in Virginia
}

\author{
Changwoo $\mathrm{Ahn}^{\dagger}$, Stacy Jones \\ Department of Environmental Science and Policy, George Mason University, Fairfax, VA, USA
}

\begin{abstract}
Several soil properties were studied from three young created mitigation wetlands ( $<10$ years old), which were hydrologically comparable in the Piedmont region of Virginia. The properties included soil organic matter (SOM), soil organic carbon (SOC), pH, gravimetric soil moisture, and bulk density $\left(\mathrm{D}_{\mathrm{b}}\right)$. No significant differences were found in the soil properties between the wetlands, except SOM and SOC. SOM and SOC indicated a slight increase with wetland age; the increase was more evident with SOC. Only about a half of SOC variability found in the wetlands was explained by SOM $\left(\mathrm{R}^{2}=0.499, \mathrm{p}<0.05\right)$. The majority of the ratios of SOM to SOC for these silt-loam soils ranged from 2.0 to 3.5, which was higher than the 1.724 Van Bemmelen factor, commonly applied for the conversion of SOM into SOC in estimating the carbon storage or accumulation capacity of wetlands. The results may caution the use of the conversion factor, which may lead to an overestimation of carbon sequestration potentials of newly created wetlands. SOC, but not SOM, was also correlated to $D_{b}$, which indicates soil compaction typical of most created wetlands that might limit vegetation growth and biomass production, eventually affecting carbon accumulation in the created wetlands.
\end{abstract}

Keywords: Bulk density, Created mitigation wetland, Soil organic matter, Soil organic carbon, Van Bemmelen factor, Wetland soils

\section{Introduction}

Soil properties are critical indicators of wetland quality [13]. Soil physicochemical properties support important biogeochemical processes that support wetland ecosystem services, but are often found in created wetlands not indicative of 'hydric soils', which is typical of natural wetlands [4]. Moreover, failures of created/restored wetlands are partially attributable to the lack of developments in soil properties [2, 5-7]. Soil development in created wetlands would take a long period of time because it requires plant and litter development with their increasing biomass [8-10]. With increasing age, the soil properties of a created wetland should develop, which may increase the storage of organic matter/carbon.

An excellent indicator of soil development and quality is the soil organic matter (SOM) content of wetlands $[1,11]$. SOM is a primary energy source being derived from litter fall, root turnover, and microbial organisms; it is one of the most telling indicators of wetland maturity $[1,11,12]$. SOM accumulates in wetland ecosystems over time [12], being an important source of nutrients (e.g., nitrogen and phosphorus). SOM also influences root development, water retention, water infiltration rates, and cation exchange and buffering capacity, which are associated with positive functional development [13, 14]. In tracking the maturation of wetland soils, most studies analyze SOM $[10,11$,
14] due to the easiness associated with the analytic method (i.e., loss on ignition [LOI]) [15].

Soil organic carbon (SOC), being a significant portion of SOM, has also been a useful indicator of soil quality and has been found to be correlated to a great number of specific soil processes that occur in wetlands, such as respiration, denitrification, and phosphorus sorption [3, 11, 14]. SOC is comprised from $48 \%$ to $58 \%$ of the total weight of SOM [16]. Moreover, SOC is often used to estimate carbon accumulation or sequestration potential in created wetlands [17]. The Van Bemmelen factor $(=1.724)$ has been used to easily convert measurable SOM to SOC based on the assumption that SOM contains $58 \%$ of SOC [16]; however, many studies have revealed that SOM is highly variable for a range of soils and thus, there may not be a single factor applicable for all types of soils.

The goal of the study was to investigate SOM and SOC contents along with other soil properties of created wetlands that are important in ecosystem development within the northern Piedmont region of Virginia. We studied the soil properties from three young created mitigation wetlands (i.e., 1-8 years old), which included SOM, SOC, $\mathrm{pH}$, gravimetric soil moisture (GSM), and bulk density $\left(\mathrm{D}_{\mathrm{b}}\right)$. The study had two specific objectives. First, the study investigated whether soil properties differ between the created wetlands of different ages; second, it examined the ratios of SOM to SOC in order to see if the application of the Van Bem-

Received December 01, 2012 Accepted July 11, 2013

(c) This is an Open Access article distributed under the terms of the Creative Commons Attribution Non-Commercial License (http://creativecommons. org/licenses/by-nc/3.0/) which permits unrestricted non-commercial use, distribution, and reproduction in any medium, provided the original work is properly cited.
${ }^{\dagger}$ Corresponding Author

E-mail: cahn@gmu.edu

Tel: +1-703-993-3978 Fax: +1-703-993-1066 
melen conversion factor can correctly represent the SOC content in these wetlands.

\section{Materials and Methods}

\subsection{Site Description}

Field research was carried out in 2007 at three created mitigation wetlands in northern Virginia, USA (annual precipitation, $99.75 \mathrm{~cm}$; mean annual temperature, $\min 2.0^{\circ} \mathrm{C} / \max 24.0^{\circ} \mathrm{C}$ ). The created wetlands were Loudoun County (LC; $39^{\circ} 02.05^{\prime} \mathrm{N}$, $77^{\circ} 36.5^{\prime} \mathrm{W}$ ), Bull Run (BR; $38^{\circ} 51.3^{\prime} \mathrm{N}, 77^{\circ} 36.05^{\prime} \mathrm{W}$ ), and North Fork (NF; $38^{\circ} 49.4^{\prime} \mathrm{N}, 77^{\circ} 40.2^{\prime} \mathrm{W}$ ) mitigation banks, all built by Wetland Studies and Solutions, Inc. in 2006, 2002, and 1999, respectively. All sites are located in the Piedmont physiogeographic province of northern Virginia, just about $40 \mathrm{~km}$ southwest of Washington, DC. The Piedmont is generally characterized by a rolling terrain underlain by igneous and metamorphic rocks [18].

LC is a 32-acre wetland, constructed in the mid-summer/ early-fall of 2006, in LC, Virginia. The site (when mature) should consist of 9.5 acres of palustrine, forested wetlands; 4 acres of preserved and enhanced, existing wetlands; 11 acres of reforested uplands; and 7.5 acres of preserved, existing upland forest. The site is located within the Big Branch Creek floodplains (to the east), a tributary of Goose Creek. There were specific conditions to note for LC. The LC wetland consists of two contiguous sites (i.e., LC1 and LC2) separated by a berm with a drainage trench, and LC1 approximately $0.4 \mathrm{~m}$ higher in position than LC2. This design primarily causes LC1 to drain quickly, leaving it inundated only for very short periods during and after precipitation, whereas LC2 remains under standing water (i.e., $<12$ $\mathrm{cm}$ ) for several months. With the difference in the hydrologic regime, we decided to treat $\mathrm{LC} 1$ and LC2 as separate sites, and chose LC2 as one of our study sites due to its similar hydrologic setting as the other two sites. Vegetation is entirely herbaceous with planted woody stems interspersed throughout. Soil is predominantly Albano silt-loam and Bermudian silt-loam. BR is a 50-acre wetland, constructed in 2002 in Prince William County, Virginia. The site consists of 24 acres of created, restored, or enhanced wetlands: 0.6 acres of open water; 3 acres of preserved wetlands; and 17 acres of preserved or reforested upland buffers. The site's primary hydrologic source overflows from the adjacent BR stream (average of one overflow event every 37 days), which sharply curves around the northeast corner of the site. Another water body, Catharpin Creek, runs through the western edge of the site, but provides no hydrologic input. Soil is predominantly Albano silt-loam and Bermudian silt-loam. Vegetation is predominantly herbaceous with forested buffers along both of the stream's flood plains. NF is a 125 -acre created wetland, constructed in 1999 in Prince William County, Virginia. The site consists of 42 acres of upland buffer, 76 acres of wetlands, and 7 acres of open water that is managed by an artificial dam structure. Vegetation is mostly herbaceous, with patches of shrub/scrub. Soils are generally silt loams and partially silty clay loams over the Newark Supergroup basalt and sandstone/siltstone formations of the Culpeper basin.

All sites were hydroseeded during the construction with the same plant seed mix purchased from a local nursery. The different ages of the created wetlands allow for our proposed study across various stages of soil and vegetative community development.

\subsection{Site Hydrology}

At each site, the depth to water table was monitored using a $70-\mathrm{cm}$ slotted well, constructed of a 3.18- $\mathrm{cm}\left(=1^{1 / 4} /\right)$ polyvinyl chloride (PVC) pipe. There were several wells established in the wetlands by the builder as part of their legal, post-construction monitoring: two in LC2, three in BR, and six in NF. The wells are located in the vicinity of our study plots at each wetland site, recording the depth to water table hourly. Water table depths were manually monitored and downloaded monthly. The water table depth data for the year 2007, when the soils were studied, were analyzed.

\subsection{Soil Sampling and Field Measurements}

For the study, we randomly established 17 plots $(10 \mathrm{~m} \times 10 \mathrm{~m}$ each) throughout the wetlands (i.e., 4 plots in LC2, 7 plots in BR, and 6 plots in NF). Soil samples were collected at the end of the growing season, September-October 2007. A soil probe/auger was used to collect the top $10 \mathrm{~cm}$ of soil, excluding the surface litter. The plots were divided into quadrants and a $1-\mathrm{m}^{2}$ grid was randomly tossed to select the sampling points within each quadrant. Triplicate soil cores were taken per quadrant, combined in a polyethylene bag and transported to the lab on ice in a cooler. $D_{b}$ samples were taken from each plot with a $160-\mathrm{mL}$ volume tin. Samples were placed in labeled Ziploc bags and stored in a cooler during transport. In the laboratory, samples were manually homogenized and visible roots and rocks were removed prior to further processing. The samples were processed immediately for physical and chemical analysis upon arrival at the laboratory.

\subsection{Soil Physicochemical Analysis}

To determine SOM, SOC, and $\mathrm{pH}$, the soils were air dried. Once air dried, they were macerated using a mortar and pestle, and large constituents (e.g., rocks and large organic debris) were removed. SOC was determined by $\mathrm{HCl}$ vapor digestion followed by a dry combustion on an elemental analyzer (PerkinElmer 2400 Series II CHNS/O Analyzer; Perkin-Elmer Corporation, Norwalk, CT, USA). Sub-samples (2-3 g of air dried soil) were separated for SOM and oven dried at $105^{\circ} \mathrm{C}$ for $24 \mathrm{hr}$, weighed and placed at $405^{\circ} \mathrm{C}$ for $16 \mathrm{hr}$ (i.e., LOI method) [15]. For GSM, the field-wet mass was measured and the samples were dried at $105^{\circ} \mathrm{C}$ for 48 hr. GSM was calculated by the difference between field moist mass and oven dried mass [(wet mass - dry mass) /(dry mass) $\times$ 100] [19]. For $\mathrm{pH}$ determination, $10 \mathrm{~g}$ of air dried soil samples were combined with $10 \mathrm{~mL}$ of deionized water, swirled and left to stabilize for $10 \mathrm{~min}$ prior to measurement [20]. $\mathrm{D}_{\mathrm{b}}$ was determined for each core, first by weighing the entire field-moist core, then converting to dry weight based on GSM percentage, and dividing by the total volume of the soil in the core $\left(200.2 \mathrm{~cm}^{3}\right)$.

\subsection{Data Analyses}

One-way analysis of variance with Tukey HSD multiple comparison test was performed in order to detect differences in all soil attributes measured among the wetlands at a $5 \%$ significance level. Bivariate regression coefficients were calculated to determine the degree of correlation between variables. All statistical analyses were carried out using Minitab ver. 15, and tests were considered to be significant at $\alpha=0.05$, unless otherwise noted. 


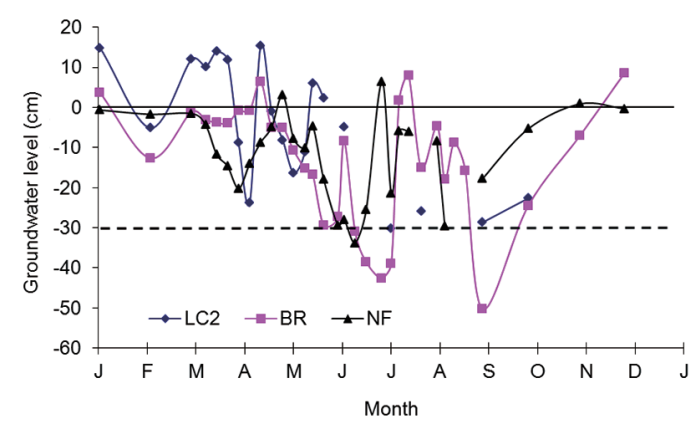

Fig. 1. Mean water table depths ( \pm standard error) of three wetland sites, LC2, BR, and NF during the growing season of 2007. The solid line represents ground surface. The dashed line represents $30 \mathrm{~cm}$ below the ground surface, the depth at and above which saturation to the surface is required in Virginia for a consecutive number of days for at least $12.5 \%$ of the growing season to satisfy the wetland hydrology criterion. LC2: Loudoun County site 2, BR: Bull Run, NF: North Fork.

\section{Results and Discussion}

\subsection{Site Hydrology}

Water table depth is assessed in the created wetlands mostly for determining the success of mitigation projects [21]. Mean water table depths at the three wetland sites all met the legal criteria for wetland hydrology (i.e., saturation or inundation within $30 \mathrm{~cm}$ of the soil surface for a consecutive number of days for at least $12.5 \%$ of the growing season [22] (Fig. 1). The mean water table depths for LC2, BR, and NF during the growing season (April through October) were $-5.0 \pm 3.5 \mathrm{~cm},-12.8 \pm 2.72$, and $-11.2 \pm$ 2.01 (mean \pm standard error), respectively. During the early growing season, the LC2 remained slightly inundated with standing water, and the water table depth was above or near the surface until mid-June (Fig. 1). During the rest of the growing season, the water table depth of LC2 was mostly below the surface, exposing soils at the site, but remained fairly at and above $30 \mathrm{~cm}$ below the surface (Fig. 1). BR and NF sites followed a similar pattern as LC2 overall, with little standing water during the growing season, yet fully saturated, thus meeting the legal criteria of hydrology (Fig. 1).

\subsection{Soil Properties of Created Wetlands}

Table 1 presents the results of the soil physicochemistry studied. Bulk densities of the three created wetlands ranged from 0.84 to $1.21 \mathrm{~g} / \mathrm{cm}^{3}$, indicating typical mineral soil characteristics of created wetlands [21]. The $\mathrm{D}_{\mathrm{b}}$ of $\mathrm{LC}$, the youngest created wetland, was relatively higher than that of $\mathrm{BR}$, which was comparable to that of NF (Table 1). $D_{b}$ tends to be high in newly created wetland soils compared to natural wetland soils into which more organic materials become incorporated [21]. $D_{b}$ is also a good indicator for soil compaction, which is common with many created wetlands [23-25]. Soil compaction increases $\mathrm{D}_{\mathrm{b}}$ and decreases pore volume [26]. Due to the heavy machinery used during the construction, most created wetlands suffer from a certain degree of soil compaction, which leads to higher $\mathrm{D}_{\mathrm{b}}$. Compaction is of particular concern for plant growth in created wetlands because it affects seed germination and early root growth [27]. Compaction can also cause other adverse effects that are associated with poor soil quality (e.g., reduced infiltration, increased runoff, lower soil temperature, and reduced rates of nutrient cycling) [26, 27]. $D_{b}$ higher than what was found in this study (i.e., over $1.55 \mathrm{~g} /$ $\mathrm{cm}^{3}$ ) is known to adversely affect plant root growth and development, particularly for silty loam soils [26]. The $D_{b}$ values found in this study were comparable to those in literatures for created/ restored wetlands (Table 2). Soil $\mathrm{pH}$ did not show any difference between the sites, ranging from 5.5 to 5.7 , demonstrating a typical acidic characteristic of the soils of Virginia Piedmont [28]. This suggests a preponderance of acidic soils in this physiographic region, which has developed over a long period of time [29]. Mean soil moisture levels (i.e., GSM) were $25.8 \%, 21.0 \%$, and $23.0 \%$ for LC2, BR, and NF, respectively, being fairly comparable between the sites (Table 1).

SOM is an excellent indicator of soil development and quality $[1,11]$, as it is a major source of nutrients (especially N). It increases water retention, aeration, root penetration, and cation exchange and buffering capacity; further, it tends to accumulate over time [16, 30, 31]. Therefore, SOM may represent an informative index of ecosystem development in created wetlands [11]. SOM ranged between $3.5 \%$ and $5.6 \%$ with NF being significantly higher $(5.6 \%)$ than the other two younger wetlands (3.6\% on average) (Table 1). SOM is naturally accumulated through autochthonous (e.g., seasonal plant senescence) and allochthonous or allogenic (e.g., sediment brought by flooding or runoff) inputs of organic matter over time $[14,16]$. In addition, wetland soils are generally characterized by their high water holding capacity, which is largely due to higher SOM contents [30]. SOM provides both organic $\mathrm{N}$, the substrate of mineralization, and SOC, which is a required energy source of both mineralizing and heterotrophic denitrifying microbes $[31,32]$.

SOC was greatest in NF (1.71\%), followed by BR $(1.44 \%)$ and LC2 (1.14\%), displaying a clear increase with the age of wetlands (Table 1). However, SOC contents found in this study seemed to be at the low end of the SOC range found in created/restored wetlands that are comparably aged (Table 2). Soil properties are known to be interdependent with higher SOM or SOC, displacing

Table 1. Soil physicochemical properties measured for three created wetlands

\begin{tabular}{ccccccc}
\hline Wetland site & $\begin{array}{c}\text { Age } \\
(\mathbf{y r})\end{array}$ & $\mathbf{p H}$ & $\begin{array}{c}\mathrm{Db}_{\mathrm{b}} \\
\left(\mathrm{g} / \mathrm{cm}^{3}\right)\end{array}$ & $\begin{array}{c}\text { Soil moisture } \\
(\%)\end{array}$ & $\begin{array}{c}\text { SOM } \\
(\%)\end{array}$ & $\begin{array}{c}\text { SOC } \\
(\%)\end{array}$ \\
\hline LC2 & 1 & $5.6 \pm 0.04^{\mathrm{a}}$ & $1.21 \pm 0.05^{\mathrm{b}}$ & $25.8 \pm 1.0^{\mathrm{b}, \mathrm{c}}$ & $3.49 \pm 0.17^{\mathrm{a}}$ & $1.14 \pm 0.09^{\mathrm{a}}$ \\
BR & 5 & $5.5 \pm 0.05^{\mathrm{a}}$ & $0.84 \pm 0.11^{\mathrm{a}}$ & $21.0 \pm 2.9^{\mathrm{a}}$ & $3.69 \pm 0.16^{\mathrm{a}}$ & $1.44 \pm 0.05^{\mathrm{b}}$ \\
NF & 8 & $5.7 \pm 0.11^{\mathrm{a}}$ & $1.03 \pm 0.14^{\mathrm{a}, \mathrm{b}}$ & $23.0 \pm 1.9^{\mathrm{a}, \mathrm{b}}$ & $5.60 \pm 0.22^{\mathrm{b}}$ & $1.71 \pm 0.06^{\mathrm{c}}$ \\
\hline
\end{tabular}

Values are presented as mean \pm standard error.

Means in each column followed by the same letter are not significantly different across the sites at the $\mathrm{p}<0.05$ level.

$\mathrm{D}_{\mathrm{b}}$ : bulk density, SOM: soil organic matter, SOC: soil organic carbon, LC2: Loudoun County site 2, BR: Bull Run, NF: North Fork. 
compacted soil and reducing $\mathrm{D}_{\mathrm{b}}$, in addition to providing an $\mathrm{ab}$ sorptive substrate for water retention, thus increasing soil moisture (i.e., GSM) [10, 13, 30].

\subsection{Relationships among SOM, SOC, and $D_{b}$}

Fig. 2 shows a positive correlation $\left(\mathrm{R}^{2}=0.499, \mathrm{p}<0.05\right)$ between SOM and SOC from pooled data of all sites, suggesting that about a half of SOC variability found with our wetland soils could be explained by the measurements of SOM. We believe that SOM was lesser positively correlated with SOC in the created wetlands due to young age and as possible impacts of construction that included topsoil addition. Although not reported here in this paper, we also investigated natural wetlands [14] nearby the created wetlands; the relationship between SOM and SOC in the natural wetlands [14] was similar, yet much stronger (i.e., $\mathrm{R}^{2}$ $=0.8843$ )

Higher amounts of SOC can result in lower bulk densities in most soils due to the lower particle density of organic carbon compared to mineral particles [22]. The results showed that SOC had a weak, yet significantly negative relationship with $D_{b}$, whereas SOM failed to show any meaningful relationship with $\mathrm{D}_{\mathrm{b}}(\mathrm{p}=0.11)$ (Fig. 3). It appears that SOC better tracks the changes in $\mathrm{D}_{\mathrm{b}}$ than SOM.

The Van Bemmelen conversion factor $(=1.724)$ which determines the SOC content of SOM was tested by calculating the ratios of SOM to SOC and creating a frequency distribution of those values (Fig. 4). The soils in the three created mitigation wetlands were mineral soils (i.e., SOM $<20 \%$ ) [21]; the majority $(90 \%)$ of the SOM/SOC ratios generated for these silt-loam soils ranged from 2.0 to 3.5 (Fig. 4). The conventional conversion factor of 1.724 appears to be fairly low for the wetland soils in this study. Thus, if one measures SOM and applies the conversion factor to estimate SOC, it would lead to an overestimation of SOC in these young created wetlands. However, it would take more tests with wetlands soils that mature over time [14] in order to confirm the statement above for all created wetlands.

Wetlands are a large terrestrial carbon pool and present an important opportunity as carbon sinks [17, 35, 36]. Soil carbon sequestration, a process in which $\mathrm{CO}_{2}$ is stored in the soil through plant and animal residues and substances, is synthe-

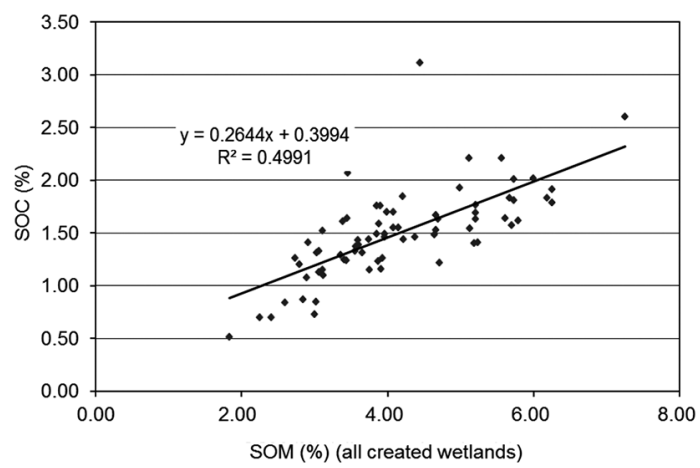

Fig. 2. Relationship between soil organic matter (SOM) and soil organic carbon (SOC) in mitigation wetlands created in the Virginia Piedmont.

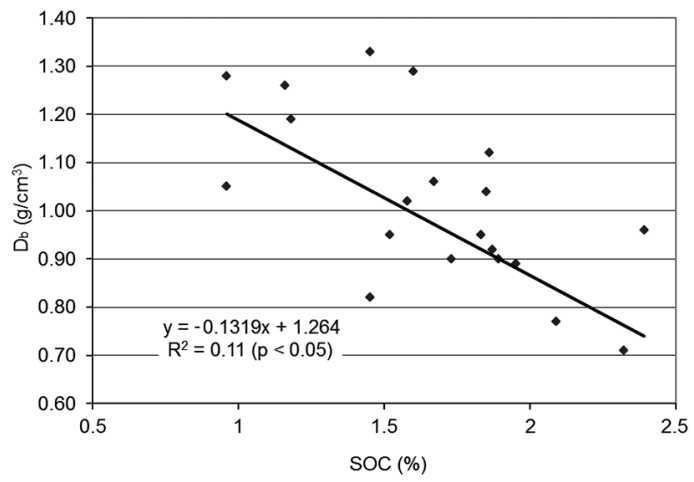

Fig. 3. Relationship between soil organic carbon (SOC) and bulk density $\left(D_{b}\right)$ in mitigation wetlands created in the Virginia Piedmont.

sized microbiologically and chemically from breakdown products in the bodies of live microorganisms and small animals [37]. It can be facilitated by creating and/or restoring wetlands [17]. Plant materials do not readily decompose due to the reducing conditions caused by flooding in wetlands, which results in the

Table 2. Literatures on soil properties including SOM and SOC contents in created/restored wetlands comparable to the current study

\begin{tabular}{lccccc}
\hline Created/restored wetlands (location) & Age (yr) & $\mathbf{D}_{\mathbf{b}}\left(\mathbf{g} / \mathbf{c m}^{3}\right)$ & SOC (\%) & SOM (\%) & Source ref. \\
\hline 44 wetlands (PA) & $1-8$ & $1.15 \pm 0.2$ & - & $2.0-6.2$ & Bishel-Machung et al. [5] \\
11 wetlands (VA) & $4-16$ & $0.50-1.26$ & - & $3.5-14.4$ & Bruland and Richardson [11] \\
8 non-tidal forested wetlands (NC) & $3-9$ & - & - & $11.8 \pm 3.9$ & Bruland and Richardson [11] \\
3 wetlands (NC) & 4 and 8 (two restored) & $1.02-1.21$ & - & $6.87-8.73$ & Bruland and Richardson [13] \\
& 5 (created) & $1.40 \pm 0.17$ & & $2.43 \pm 0.88$ & Campbell et al. [7] \\
12 palustrine emergent wetlands (PA) & $<10$ & - & - & 3.8 & Anderson et al. [8] \\
& $>10$ & - & $3.70 \pm 0.19$ & $9.5 \pm 0.5$ & Nair et al. [23] \\
2 experimental marsh wetlands (OH) & 10 & $0.4-0.9$ & 5.6 & - & D'Angelo et al. [34] \\
Samples across 156 wetlands (FL) & 15 & 1.32 & 1.11 & - & Cole et al. [6] \\
8 riverine wetlands (KY) & $<10$ & - & - & $2.3-6.5$ & Fajardo [24] \\
7 palustrine wetlands (PA) & $5-20$ & $0.98-1.59$ & $0.85-2.32$ & - & Giese et al. [33] \\
10 wetlands (VA) & $2-4$ & - & $2.2-2.9$ & - & Stolt et al. [2] \\
3 riparian wetlands (SC) & 7,11 & - & - & 9.33 &
\end{tabular}

$\mathrm{D}_{\mathrm{b}}$ : bulk density, SOM: soil organic matter, SOC: soil organic carbon. 


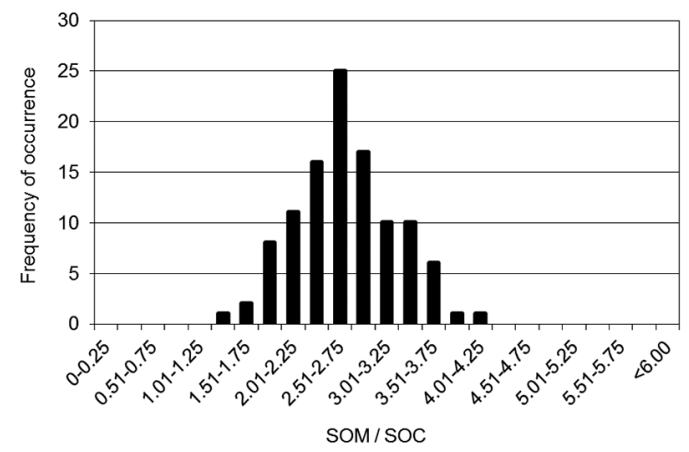

Fig. 4. Frequency of occurrence of the ratios of soil organic matter (SOM) to soil organic carbon (SOC) in created wetlands.

accumulation of organic carbon [31, 33]. In particular, young created wetlands can reduce the net $\mathrm{CO}_{2}$ emission into the atmosphere through the consumption of $\mathrm{CO}_{2}$ by actively growing wetland plants that are being established, while projecting a low chance for methane emission due to its low organic matter content. Recent studies have identified the lack of SOC in created mitigation wetlands as one of the major factors hindering the functional development to be met [38]. Most of the studies that track the progress of the ecosystem and/or soil development in created wetlands investigated SOM that is easily measurable (i.e., by LOI) and often applied the conversion factor to estimate the SOC content $[1,5,6,11]$. Based on our study, we suggest that caution should be exercised in universally using the conversion factor for a variety of soil types, and recommend that SOC be measured using a dry combustion analyzer in order to more precisely track the SOC dynamics in created wetlands. Further study is needed to test a wide range of soils for their carbon sequestration potential and to better gauge the wetland function of storing organic carbon to be developed over time in created/ restored wetlands.

\section{Conclusions}

We investigated the development of soil properties in three created mitigation wetlands in the Piedmont region of Virginia that were relatively young $(<10$ years old). The properties showed comparable values as those observed in other created/restored wetlands. SOM and SOC contents were greater in relatively older created wetlands, conveying that it takes time to build up organic matter in soils as part of wetland soil development. Soil properties are often left out in post-construction monitoring for created/restored mitigation wetlands that are required for the first five years because the monitoring usually focuses on hydrology and vegetation [39]. To truly track the development of ecosystem functions, such as carbon and nutrient sequestration potentials, soil properties should be monitored regularly over a longer period of time. In addition, the outcome of the study revealed that Van Bemmelen SOM to SOC conversion factor may not be universally applied to wetland soils for estimating SOC from SOM. In addition, SOC turned out to be more sensitive than SOM to changes in $\mathrm{D}_{\mathrm{b}}$ that indicate soil compaction, which might limit vegetation growth and biomass production, eventually affecting carbon sequestration in created wetlands.

\section{Acknowledgments}

We thank Wetland Studies and Solutions, Inc. for the use of their created mitigation wetlands. Ahn Wetland Ecosystem Lab members assisted in soil sampling and analysis.

\section{References}

1. Shaffer PW, Ernst TL. Distribution of soil organic matter in freshwater emergent/open water wetlands in the Portland, Oregon metropolitan area. Wetlands 1999;19:505-516.

2. Stolt MH, Genthner MH, Daniels WL, Groover VA, Nagle S, Haering KC. Comparison of soil and other environmental conditions in constructed and adjacent palustrine reference wetlands. Wetlands 2000;20:671-683.

3. Ahn C, Peralta RM. Soil properties are useful to examine denitrification function development in created mitigation wetlands. Ecol. Eng. 2012;49:130-136.

4. National Research Council. Compensating for wetland losses under the Clean Water Act. Washington: National Academy Press; 2001.

5. Bishel-Machung L, Brooks RP, Yates SS, Hoover KL. Soil properties of reference wetlands and wetland creation projects in Pennsylvania. Wetlands 1996;16:532-541.

6. Cole CA, Brooks RP, Wardrop DH. Assessing the relationship between biomass and soil organic matter in created wetlands of central Pennsylvania, USA. Ecol. Eng. 2001;17:423-428.

7. Campbell DA, Cole CA, Brooks RP. A comparison of created and natural wetlands in Pennsylvania, USA. Wetland Ecol. Manag. 2002;10:41-49.

8. Anderson CJ, Mitsch WJ, Nairn RW. Temporal and spatial development of surface soil conditions at two created riverine marshes. J. Environ. Qual. 2005;34:2072-2081.

9. Anderson CJ, Mitsch WJ. Sediment, carbon, and nutrient accumulation at two 10-year-old created riverine marshes. Wetlands 2006;26:779-792.

10. Ballantine K, Schneider R. Fifty-five years of soil development in restored freshwater depressional wetlands. Ecol. Appl. 2009;19:1467-1480.

11. Bruland GL, Richardson CJ. Comparison of soil organic matter in created, restored and paired natural wetlands in North Carolina. Wetlands Ecol. Manag. 2006;14:245-251.

12. Odum EP. The strategy of ecosystem development. Science 1969;164:262-270.

13. Bruland G, Richardson CJ. Spatial variability of soil properties in created, restored, and paired natural wetlands. Soil Sci. Soc. Am. J. 2005;69:273-284.

14. Wolf KL, Ahn C, Noe GB. Development of soil properties and nitrogen cycling in created wetlands. Wetlands 2011;31:699712 .

15. Nelson DW, Sommers LE. Total carbon, organic carbon, and organic matter. In: Sparks DL, ed. Methods of soil analysis. Part 3: Chemical methods. Madison: Soil Science Society of America; 1996. p. 961-1010.

16. Collins ME, Kuehl RJ. Organic matter accumulation and organic soils. In: Richardson JL, Vepraskas MJ, eds. Wetland soils: genesis, hydrology, landscapes, and classification. Boca Raton: Lewis Publishers; 2001. p. 137-161.

17. Besasie NJ, Buckley ME. Carbon sequestration potential at central Wisconsin wetland reserve program sites. Soil Sci. Soc. Am. J. 2012;76:1904-1910. 
18. Hook DD, McKee WH Jr, Williams TM, Jones S, Van Blaricom D, Parsons J. Hydrologic and wetland characteristics of a Piedmont bottom in South-Carolina. Water Air Soil Pollut. 1994;77:293-320.

19. Gardner WH. Water content. In: Klute A, ed. Methods of soil analysis. Part 1: Physical and mineralogical methods. 2nd ed. Madison: Soil Science Society of America; 1986. p. 493-544.

20. Thomas GW. Soil pH and soil acidity. In. Sparks DL, ed. Methods of soil analysis. Part 3: Chemical methods. Madison: Soil Science Society of America; 1996. p. 475-490.

21. Mitsch WJ, Gosselink JG. Wetlands. 3rd ed. New York: John Wiley \& Sons; 2000.

22. Federal Interagency Committee for Wetland Delineation. Federal manual for identifying and delineating jurisdictional wetlands. Washington: US Army Corps of Engineers; 1989.

23. Nair VD, Graetz DA, Reddy RK, Olila OG. Soil development in phosphate-mined created wetlands of Florida, USA. Wetlands 2001;21:232-239.

24. Fajardo GI. Physical and chemical soil properties of ten Virginia Department of Transportation (VDOT) mitigation wetlands [master's thesis]. Blacksburg: Virginia Polytechnic Institute and State University Master Thesis, 2006.

25. Moser K, Ahn C, Noe G. Characterization of microtopography and its influence on vegetation patterns in created wetlands. Wetlands 2007;27:1081-1097.

26. Logsdon SD, Karlen DL. Bulk density as a soil quality indicator during conversion to no-tillage. Soil Tillage Res. 2004;78:143-149.

27. Petru BJ, Ahn C, Cheschier G. Alteration of soil hydraulic properties during the construction of mitigation wetlands in the Virginia Piedmont. Ecol. Eng. 2013;51:140-150.

28. Farrell JD, Ware S. Edaphic factors and forest vegetation in the Piedmont of Virginia. Bull. Torrey Bot. Club 1991;118:161169.
29. Sherwood WC, Hartshorn AS, Eaton LS. Soils, geomorphology, landscape evolution, and land use in the Virginia Piedmont and Blue Ridge. GSA Field Guide 2010;16:31-50.

30. Reddy KR, DeLaune RD. Biogeochemistry of wetlands: science and applications. Boca Raton: CRC Press; 2008.

31. Sollins P, Glassman C, Paul EA, et al. Soil carbon and nitrogen: pools and fractions. In: Robertson GP, et al, eds. Standard soil methods for long-term ecological research. New York: Oxford University Press; 1999. p. 89-105.

32. Beauchamp EG, Trevors JT, Paul JW. Carbon sources for bacterial denitrification. Adv. Soil Sci. 1989;10:113-142.

33. Giese LA, Aust WM, Trettin CC, Kolka RK. Spatial and temporal patterns of carbon storage and species richness in three South Carolina coastal plain riparian forests. Ecol. Eng. 2000;15:S157-170.

34. D'Angelo EM, Karathanasis AD, Sparks EJ, Ritchey SA, WehrMcChesney SA. Soil carbon and microbial communities at mitigated and late successional bottomland forest wetlands. Wetlands 2005;25:162-175.

35. Euliss NH Jr., Gleason RA, Olness A, et al. North American prairie wetlands are important nonforested land-based carbon storage sites. Sci. Total Environ. 2006;361:179-188.

36. Kayranli B, Scholz M, Mustafa A, Hedmark A. Carbon storage and fluxes within freshwater wetlands: a critical review. Wetlands 2010;30:111-124

37. Lal R. Carbon sequestration. Philos. Trans. R. Soc. Lond. B Biol. Sci. 2008;363:815-830.

38. Hossler K, Bouchard V. Soil development and establishment of carbon-based properties in created freshwater marshes. Ecol. Appl. 2010;20:539-553.

39. Spieles DJ. Vegetation development in created, restored, and enhanced mitigation wetland banks of the United States. Wetlands 2005;25:51-63. 